190

ANL/ES-23

$7-1 T-73$

CHLORINATION EXPERIMENTS AT THE

JOHN E. AMOS PLANT OF THE

APPALACHIAN POWER COMPANY:

APRIL 9-10, 1973

J. E. Draley

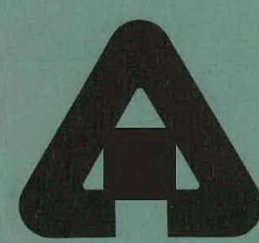

ARGONNE NATIONAL LABORATORY, ARGONNE, ILLINOIS

Prepared for the U.S. ATOMIC ENERGY COMMISSION under Contract W-31-109-Eng-38 


\section{DISCLAIMER}

This report was prepared as an account of work sponsored by an agency of the United States Government. Neither the United States Government nor any agency Thereof, nor any of their employees, makes any warranty, express or implied, or assumes any legal liability or responsibility for the accuracy, completeness, or usefulness of any information, apparatus, product, or process disclosed, or represents that its use would not infringe privately owned rights. Reference herein to any specific commercial product, process, or service by trade name, trademark, manufacturer, or otherwise does not necessarily constitute or imply its endorsement, recommendation, or favoring by the United States Government or any agency thereof. The views and opinions of authors expressed herein do not necessarily state or reflect those of the United States Government or any agency thereof. 


\section{DISCLAIMER}

Portions of this document may be illegible in electronic image products. Images are produced from the best available original document. 
The facilities of Argonne National Laboratory are owned by the United States Government. Under the terms of a contract (W-31-109-Eng-38) between the U. S. Atomic Energy Commission, Argonne Universities Association and The University of Chicago, the University employs the staff and operates the Laboratory in accordance with policies and programs formulated, approved and reviewed by the Association.

\section{MEMBERS OF ARGONNE UNIVERSITIES ASSOCIATION}

The University of Arizona Carnegie-Mellon University Case Western Reserve University The University of Chicago University of Cincinnati Illinois Institute of Technology University of Illinois Indiana University Iowa. State University The University of Iowa
Kansas State University The University of Kansas Loyola University Marquette Univer sity Michigan State University The University of Michigan University of Minnesota University of Missouri Northwestern University University of Notre Dame
The Ohio State University Ohio University The Pennsylvania State University Purdue University Saint Louis University Southern Illinois University The University of Texas at Austin Washington University Wayne State University The University of Wisconsin

\section{NOTICE}

This report was prepared as an account of work sponsored by the United States Government. Neither the United States nor the United States Atomic Energy Commission, nor any of their employees, nor any of their contractors, subcontractors, or their employees, makes any warranty, express or implied, or assumes any legal liability or responsibility for the accuracy, completeness or usefulness of any information, apparatus, product or process disclosed, or represents that its use would not infringe privately-owned rights.

Printed in the United States of America

Available from

National Technical Information Service

U.S. Department of Commerce 5285 Port Royal Road

Springfield, Virginia 22151

Price: Printed Copy $\$ 4.00$; Microfiche $\$ 0.95$ 
ARGONNE NATIONAL LABORATORY

9700 South Cass Avenue

Argonne, Illinois 60439

\section{CHLORINATION EXPERIMENTS AT THE JOHN E. AMOS PLANT OF THE \\ APPALACHIAN POWER COMPANY : \\ APRIL 9-10, 1973}

by

J. E. Draley

Environmental Statement Project

June 1973

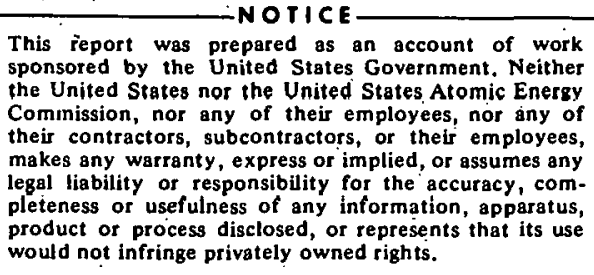

This report was prepared as an account of work sponsored by the United States Government. Neither Commission, nor their contractors, subcontractors, or their employees, makes any warranty, express or implied, or assumes any pleteness or usefulness of any information, apparatus, product or process disclosed, or represents that its use would not infringe privately owned rights. 
THIS PAGE

\section{WAS INTENTIONALLY \\ LEFT BLANK}


TABLE OF CONTENTS

Page

ABSTRACT . . . . . . . . . . . . . . . . . . . . . . 5

1. INTRODUCTION .............................. 6

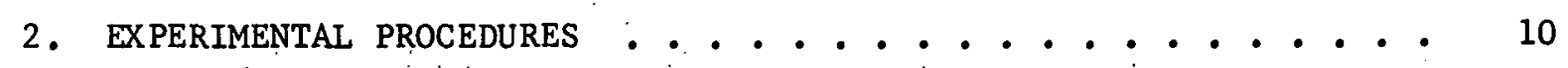

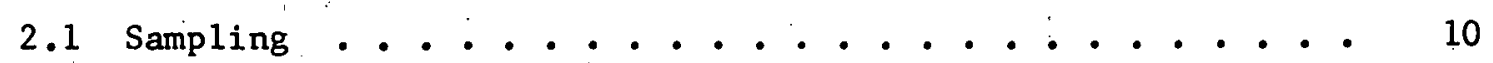

2.2 Analyses ..................... . . . 12

2.3 Operational Procedure . . . . . . . . . . . . 12

3. RESUlTS ....................... . . . . 14

4. APPLICATION OF CALCULATIONAL MODELS . . . . . . . . . . 20

ACKNOWLEDGMENTS . . . . . . . . . . . . . . . 26

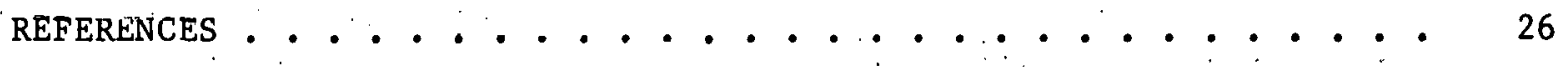




\section{LIST OF FIGURES}

№.

Title

Page

1. Cooling Tợer, Showing Sampling Location . . . . . . . . 11

2. Chlorination Run No. 1: April 9, 1973 ........... 17

3. Chlorination Run No. 2: April 10, 1973 ......... 17

\section{LIST OF TABLES}

No.

Title

Page

1. Analyses of Water of Kanawha River near Amos Plant . . . . 8

2. Analytical Results for Chlorine: Run No. 1 . . . . . . 15

3. Analytical Results for Chlorine: Run No. 2 . . . . . . 16

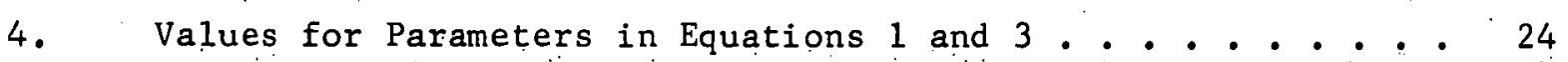




\title{
CHLORINATION EXPERIMENTS AT THE \\ JOHN E. AMOS PLANT OF THE \\ APPALACHIAN POWER COMPANY: \\ APRIL 9-10, 1973
}

\section{by}

\author{
J. E. Draley
}

\begin{abstract}
In two special runs, free and total residual chlorine were measured in the circulating-water system of the cooling tower for the Amos Plant Unit 1. For a typical chlorination period, in which the concentration of free chlorine at the condenser was about $0.1 \mathrm{ppm}$, the total residual-chlorine concentration reached maxima of $0.63 \mathrm{ppm}$ at the condenser discharge and $0.32 \mathrm{ppm}$ in the discharge from the cooling-tower basin. These residualchlorine levels declined after the addition of chlorine was stopped, but more than $2 \mathrm{hr}$ elapsed before the residual chlorine could no longer be detected by the amperometric-titration method (sensitivity perhaps 0.01 or $0.02 \mathrm{ppm}$ ).

The data for the buildup of residual chlorine at the condenser were fitted with a kinetic expression in which some reduction of chlorine to chloride and some formation of chloramines are assumed. Good fits, with reasonable values of the constants, suggest that the model is correct.

'The data for gradual decay of combined chlorine were fitted with an equation based on a model in which the chlorine is as sumed to be lost in the blowdown and by processes within the system. Again, good fits, with reasonable parameters, gave credence to the model. The calculated fraction of the chloramines lost per pass through the circulating-water system was 0.4 .
\end{abstract}




\section{INTRODUCTION}

Maintenance of the quality of our environment requires, among other things, that the release of chemicals be kept to the minimum commensurate with effective operation of power- or product-producing plants. In the preparation of Environmental Impack Statements for construction or operation of nuclear plants to ensure control of such releases, the Atomic Energy Commission, together with its contractors, often must estimate the amounts of substances (such as rhlorino), relcased tú Llie envirónment without having factual information that will ensure accuracy of the estimation.

In many respects, chlorine is an ideal defouling agent because its high toxicity to fouling organisms is accompanied by its inherent instability in water.' 1,2 The instability is of two types: (a) Free chlorine (i.e., hypochlorous acid) decomposes in water to liberate nxygen and produce chloride ion; Llils reaction is markedly accelerated by ultraviolet light so that the chlorine is in this way dissipated rapidly in the presence of sunlight. (Rates of this type of reaction for combined chlorine are unknown.) (b) Chlorine reacts with constituents of natural waters that will reduce it to the innocuous chlorite ion. Theac solutes include inorganic reducing agents and organic substances. In addition, biological slimes on the walls of the parts of the cooling-water system at power plants will reduce chlorine.

Ideally, the chlorine should be added at a level and location that will allow maintenance of effective concentrations at the point needed and still allow the chlorine to decay to innocuous levels before discharge to the environment. Unfortunately, rates of decay for actual cases 
cannot be predicted, because many of the specific reaction rates are unknown and because rates of reaction vary with the organic material from system to system and perhaps from season to season.

Partly because of this variability, predicting decay rates and developing optimum chlorination plans purely on the basis of empirical relationships are not likely. Instead, it is felt necessary to develop.a method of calculating effects for new plants that is solidly based on data from existing plants. The measurements given in this report were therefore taken so that useful calculational models could be developed for predicting the release of chlorine in the blowdown water from recirculating-coolingwater systems using cooling towers and for developing chlorination management procedures.

The John E. Amos Plant of the Appalachian Power Company at St. Albans, West Virginia, which burns coal, has two 800 -MWe net units operating. (Unit 2 was down on the days of the measurements.) Each plant has its own circulatingwater system, and each has its own natural-draft cooling tower. Some useful paramelers for Unit 1 are as follows: The total volume of the circulatingwater system is 5.5 million gal; the circulating-water flow rate is $248,000 \mathrm{gpm}$; the makeup rate varies, with a maximum of about $7000 \mathrm{gpm}$. The water in the blowdown (4000 $\mathrm{gpm}$ for $1-1 / 2$ hours per day) is used to transport ashes from the furnaces to ash-drainage pits, from which the overflow picks up fly ash and carries that to a pond in which the ash settles; the overflow from this pond then is released to the Kanawha River. Some information on the chemistry of the Kanawha River water used for makeup is shown in Table 1. The $\mathrm{pH}$ of the circulating water is adjusted by automatic 
TABLE 1. Analyses of Water of Kanawha River near Amos Plant

March 1973 (8 analyses):

M. 0. alkalinity, ppm $\mathrm{CaCo}_{3}$

$38-63$

Total hardness, ppm $\mathrm{CaCO}_{3}$

51-68

Chloride, ppm

$7-15$

Sulfate, ppm

20-40

$\mathrm{pH}$

$7.32-7.90$

Turbidity

Total solids, ppm

$<25-92$

100-508 (second highest TS $=264$ )

Seplember lu-Uctober 27, 1972

(range and mean of 5 analyses):

$\mathrm{pH}$

$6.71-7.30(6.96)$

Spec. conductance, $\mathrm{ohm}^{-1} \mathrm{~cm}^{-1}$

201-463 (268)

Aluminum, $\mathrm{ppb}$

$5-42$ (21)

Antimony, $\mathrm{ppb}$

$1-23$ (8)

Hardness, ppm $\mathrm{CaCO}_{3}$

65-122 (83)

Barium, ppb

2-29 (24)

Boron, ppm

$0.02-0.05 \quad(0.03)$

Bromine, ppm

$<0.04$

Calcium, ppm

$18-37$ (24)

Gopper, ppis

5-17 (11)

Iron, $\mathrm{ppb}$

15-300 (103)

Lead, ppb

0-2 (1)

Mağueslum, ppm

4.5-7.0 (5.6)

Manganese, ppm

4-59 (29)

Nicke1, ppb

2-4

Nitrate, ppm

$2.6-5.6(4.3)$

Phọsphorus, ppm

$<0.1-0.2$

Potassium, ppm

1.9-4.2 (2.5)

Sodium, ppm

$10.5-39.0(20.3)$

Tin, ppb

0-3 (1)

Zinc, ppb

10-340 (150) 
addition of sulfuric acid to maintain a level at which calcium carbonate will not precipitate in the system. The normal $\mathrm{pH}$ of operation is usually fairly close to 7.5. Since water is taken from the circulating-water system as blowdown only for about 90 minutes a day, the dissolved-solids content of the recirculating water is much higher than that in the river. (The concentration factor is calculated to be about 28 , as an average, for the operating parameters given above.) 


\section{EXPERIMENTAL PROCEDURES:}

\subsection{Sampling}

Samples were taken from two locations--immediately. following the left condenser, and the outlet of the cooling-tower basin (see Fig. 1).: The condenser-exit sample passed through about $260 \mathrm{ft}$ of $3 / 4-1$-diameter copper pipe at about $7.6 \mathrm{gpm}$ before reaching the open cup from which 1 t was dippered out. About $3 / 4$ min was therefore roquired for llie sample to pass from the point of sampling at the condenser to the point of removal for analysis. An estimated additional one minute was required for passage of the water from the point of chlorine injection to the condensers.

The cooling-tower-basin sample was removed from the sluice that passes cold water from the basin (about $6 \mathrm{ft}$ deep). th the point of chlorine injection and to the pumps (there about $13 \mathrm{ft}$ deep), by use of a longhandled (about 8 ft long) polyethylenc dipper. For all samples after the first few of the first run, the dipper was inserted in the water as deeply as conveniently possible (about 4-1/2 ft) and quickly withdrawn. The sample, undoubtedly, was partly mixed with water at levels higher than the 4-1/2-ft level during the withdrawal, but the procedure seemed the best readily available. Samples near the surface of the water flowing in the sluice, such as were taken for the first few times, evidently were poorly representative of the water from the cooling-tower basin. The surface water probably is largely composed of the water falling from the coolingtower periphery close to the opening to the sluice. In addition, the wind-driven surface currents, highly variable, led to variable times of 


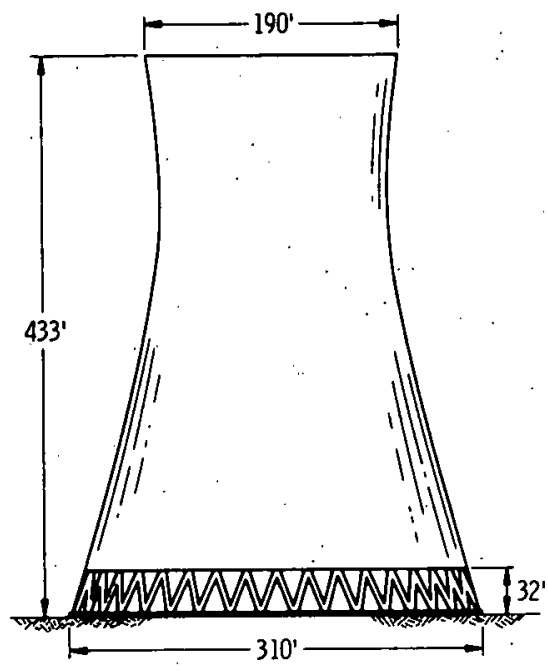

COOLING TOWER ELEVATION

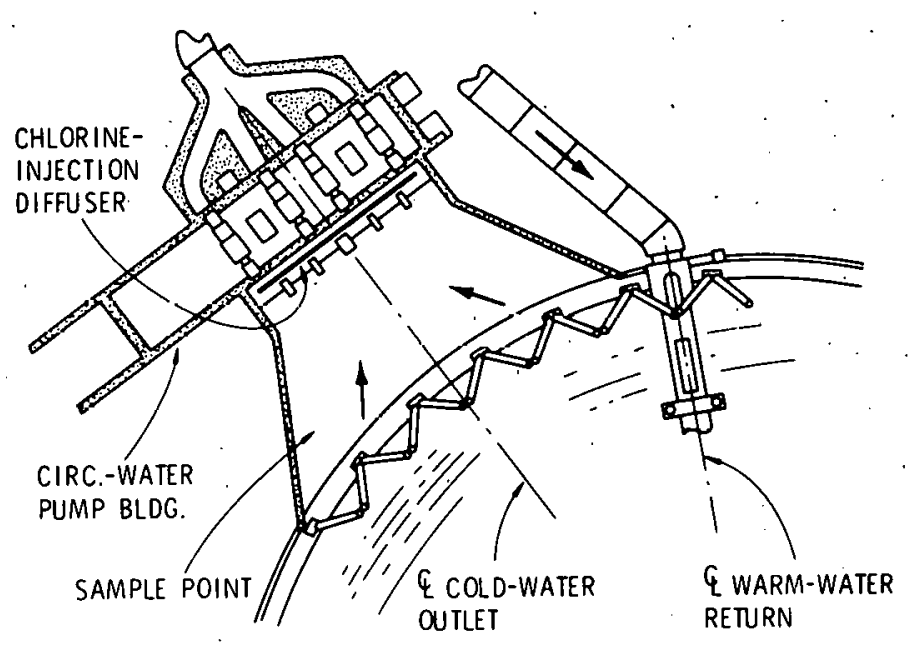

PARTIAL PLAN VIEW

Fig. 1. Cooling Tower, Showing Sampling Location 
passage from the near point of the cooling-tower discharge to the point of sampling.

\subsection{Analyses}

After removal from the open source (at either location), amperometric titration for free or combined chlorine, or both, was made with portable Wallace and Tiernan equipment. The titrations for cooling-tower-basin samples were carried nut outdoorg because excessive losses of chlorine III Ihe occur in the tIme required to transport the samples indoors. Shielding the samples from the sunlight was necessary during transportation to the nearby titration equipment and during titration. On the day of the first run (April 9), this shielding was done crudely by holding a jacket above the sample or the equipment.' For the second run (April 10), all titrations were done inside a station wagon, with windows blacked out by covering with opaque plastic sheeting.

\subsection{Operational Procedure}

The chlorine was injected as an aqueous solution at a constant rate. The flow was started and stopped manually; the injection period for both runs was $30 \mathrm{~min}$. Chlorine injection rates were 2.71 and $3.331 \mathrm{~b} / \mathrm{min}$ for Runs 1 and 2 , respectively; calculated chlorine concentrations at the point of injection were thus 1.31 and $1.61 \mathrm{ppm}$ for Runs 1 and 2 . 
During Run 1, blowdown was being taken from the circulating-water system at a rate that was not measured; presumably it was the standard $4000 \mathrm{gpm}$. During Run 2, there was no blowdown.

Titrations for free chlorine in the condenser samples of Run 1 were difficult because of the slowness with which the electrode current (shown by the needie of the measuring microammeter) changed on addition of the standard reducing agent. On this basis, it was decided that the use of a pH 7 buffer would be beneficial for Run 2. However, the chemistry of the circulating water was such that the $\mathrm{pH} 4$ buffer used during the determination of combined chlorine did not overcome the buffering action of the solution plus that of the $\mathrm{pH} 7$ buffer. Accordingly, for Run 2, samples were titrated for free chlorine or total chlorine, rather than for determining both free and combined chlorine on each sample (as had been done for Run 1). 


\section{RESULTS}

Analytical results are shown for the two runs in Tables 2 and 3 and in Figs. 2 and 3.

In Run 1, the free chlorine at the condenser exit rose quickly to nearly $0.1 \mathrm{ppm}$ and then increased only slightly to the end of the addition period. During the same period, the combined chlorine increased more gradually, to a maximum measured va 1 pe of $0.53 \mathrm{ppm}$. Nu free chlorine was detected in the sluice samples. The combined chlorine reached a maximum concentration of $0.31 \mathrm{ppm}$ and then started to decline (about 12 minutes after the concentration of combined chlorine at the condenser exit started to decline).. If the free chlorine at the condenser was reduced to chloride ion before reaching the sluice, the combined-chlorine level declined about $40 \%$ between condenser and sluice. On the other hand, if most of the free chlorinc at lie condenser was converted to combined chlorine, about $50 \%$ of this combined chlorine was lost in the cuuling tower. This topic 1s analyzed further in the next section.

I'he period of gradual dccline of the combined-chlorine level has two notable features for Run 1. First, at its start, the residual-chlorine concentration was higher by a factor of three than had been hoped could be achleved in a cooling-tower-circuit blowdown, even though the excess free chlorine at the condenser exit was only $0.1 \mathrm{ppm}$. Second, the decay of residual combined chlorine was gradual. After chlorine addition was stopped, the residual chlorine in the sluice soon reached a maximum and then declined to $0.1 \mathrm{ppm}$ at about 50 minutes. An additional 90 minutes was required for the 
TABLE 2: Analytical Resülts for Chlorine: Run No. 1

\begin{tabular}{|c|c|c|c|c|c|}
\hline \multicolumn{3}{|c|}{ Condenser Exit } & \multicolumn{3}{|c|}{ Cooling-tower sluice } \\
\hline Time, a min & Free, ppm & Total, ppm & Time, $\mathrm{a}$ min & Free, ppm & Total, ppm \\
\hline 3 & 0.00 & 0.00 & $12.0 \mathrm{~b}$ & 0.00 & 0.07 \\
\hline 7 & 0.07 & 0.30 & $16.0^{\mathrm{b}}$ & 0.00 & 0.12 \\
\hline 12 & 0.08 & 0.34 & $20.0^{\mathrm{b}}$ & 0.00 & 0.15 \\
\hline 15 & 0.09 & 0.43 & $24.0^{\mathrm{b}}$ & 0.00 & 0.17 \\
\hline 19 & 0.09 & 0.49 & $27.0^{b}$ & 0.00 & 0.25 \\
\hline 23 & 0.09 & 0.56 & 29.3 & 0.00 & 0.27 \\
\hline 27 & 0.09 & 0.60 & 33.0 & 0.00 & 0.30 \\
\hline 30 & 0.10 & 0.63 & 35.8 & 0.00 & 0.31 \\
\hline 33 & 0.06 & 0.62 & 39.0 & 0.00 & 0.32 \\
\hline 38 & 0.00 & 0.31 & 43.0 & 0.00 & 0.30 \\
\hline 40 & 0.00 & 0.27 & 47.0 & 0.00 & 0.30 \\
\hline 43 & 0.04 & 0.23 & 50.0 & - & 0.25 \\
\hline 46 & $0.00^{\circ}$ & 0.19 & 52.0 & - & 0.22 \\
\hline 49 & 0.00 & 0.15 & 55.0 & $\quad-$ & 0.20 \\
\hline 52 & 0.00 & 0.14 & 58.7 & 0.00 & 0.17 \\
\hline 57 & 0.00 & 0.12 & 62.8 & 0.00 & 0.14 \\
\hline 61 & 0.00 & 0.10 & 66.5 & 0.00 & 0.14 \\
\hline 64 & 0.00 & 0.09 & 72.5 & 0.00 & 0.12 \\
\hline 68 & 0.00 & 0.08 & 77.8 & 0.00 & 0.10 \\
\hline 72 & 0.00 & 0.07 & 85.0 & 0.00 & 0.10 \\
\hline 76 & 0.00 & 0.07 & 91.0 & - & 0.08 \\
\hline 80 & 0.00 & 0.07 & 97.0 & - & 0.07 \\
\hline 82 & 0.00 & 0.06 & 103.0 & - & 0.07 \\
\hline 85 & 0.00 & 0.06 & 112.0 & - & 0.07 \\
\hline 88 & 0.00 & 0.06 & 124.0 & - & 0.05 \\
\hline 91 & 0.00 & 0.05 & 136.5 & - & 0.05 \\
\hline 93 & 0.00 & 0.05 & 150.0 & - & 0.03 \\
\hline 96 & 0.00 & 0.05 & 165.0 & - & 0.00 \\
\hline 103 & 0.00 & 0.04 & & & \\
\hline 115 & 0.00 & 0.03 & & & \\
\hline 125 & 0.00 & 0.03 & & & . \\
\hline 136 & 0.00 & 0.02 & & & \\
\hline 148 & 0.00 & 0.02 & & & \\
\hline 166 & 0.00 & 0.01 & & & \\
\hline 174 & 0.00 & 0.00 & & & \\
\hline
\end{tabular}

after turning on chlorine feed.

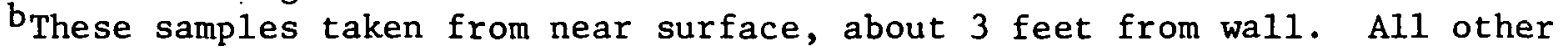
samples taken at a depth of about 4-1/2 feet (with some mixing during withdrawal), about 2 feet from wall. 
TABLE 3. Analytical Results for Chlorine: Run No. 2

\begin{tabular}{|c|c|c|c|c|c|c|c|}
\hline \multicolumn{3}{|c|}{ Condenser Exit } & \multicolumn{5}{|c|}{ Cooling-tower sluice } \\
\hline Time, ${ }^{a}$ min & Free, ppm & Total, ppm & Time, ${ }^{a} \mathrm{~min}$ & Free, ppm & & Toțal, & ppm \\
\hline$i$ & - & 0.00 & 20.0 & - & & 0.00 & \\
\hline$\overline{3}$ & - & 0.00 & 22.5 & $-i$ & & 0.10 & \\
\hline 5 & - & 0.19 & 25.0 & 0.14 & & - & \\
\hline 7 & 0.09 & - & 28.2 & - & & 0.39 & \\
\hline 9 & 0.00 & - & 32.0 & 0.00 & & - & \\
\hline 11 & - & 0.49 & 35.0 & $-\because$ & . & 0.42 & \\
\hline 13 & 0.16 & - & 38.2 & 0.00 & & - & \\
\hline 15 & - & 0.65 & 40.4 & - & & 0.51 & \\
\hline 18 & 0.00 & - & 44.7 & 0.09 & & - & \\
\hline 19 & - & 0.73 & 48.0 & - & & 0.44 & \\
\hline 21 & 0.05 & 0 & 32.0 & 0.05 & & - & \\
\hline 23 & - & 0.80 & 56.0 & - & & 0.35 & \\
\hline 25 & 0.25 & - & 60.0 & 0.00 & & - & \\
\hline 27 & 0.00 & - & 62.7 & - & & 0.31 & \\
\hline 29 & - & 0.90 & 66.3 & 0.00 & & - & \\
\hline 30 & 0.26 & - & 69.3 & - & & 0.25 & \\
\hline 32 & 0.09 & - & $74: 3$ & 0.00 & & - & \\
\hline 34 & 0.06 & - & 78.0 & - & ' & 0.23 & \\
\hline 36 & - & 0.55 & 81.0 & 0.00 & & - & \\
\hline 38. & 0.00 & - & 87.0 & - & & 0.19 & \\
\hline 40 & - & 0.42 & 90.0 & - & & 0.16 & \\
\hline 42 & 0.00 & - & 96.7 & - & & 0.15 & \\
\hline 47 & - & 0.34 & 103.3 & - & & 0.14 & \\
\hline 52 & 0.00 & $=$ & 113.3 & - & & 0.12 & \\
\hline 57 & - & 0.27 & 125.0 & - & & 0.10 & \\
\hline 65 & - & 0.21 & 135.0 & - & & 0.08 & . \\
\hline 69 & 0.00 & - & 145.0 & - & & 0.07 & \\
\hline 75 & - & 0.16 & & & & & \\
\hline 85 & - & 0.13 & & & & & \\
\hline 94 & 0.00 & - & & & & & \\
\hline 97 & - & 0.10 & & & & & \\
\hline 109 & - & 0.09 & & & & & \\
\hline 1.16 & 0.08 & - & & & & & \\
\hline 127 & - & 0.07 & & & & & \\
\hline 139 & - & 0.06 & & & & & \\
\hline
\end{tabular}

after turning on chlorine feed. 


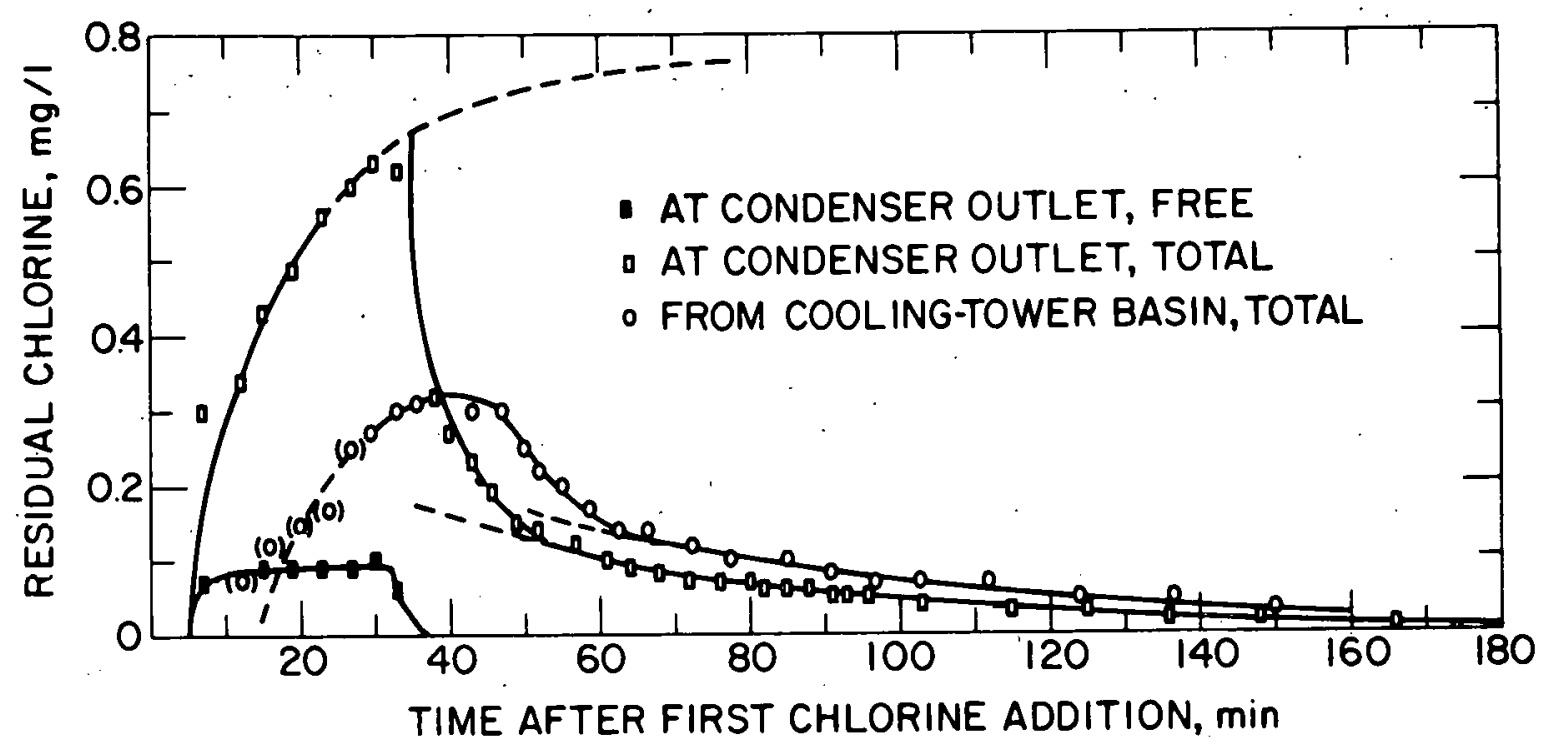

Fig. 2. Chlorination Run No. 1: Apri1 9, 1973. (Condenser exit temperature $100^{\circ} \mathrm{F}, \mathrm{pH} 7.10-7.60$. )

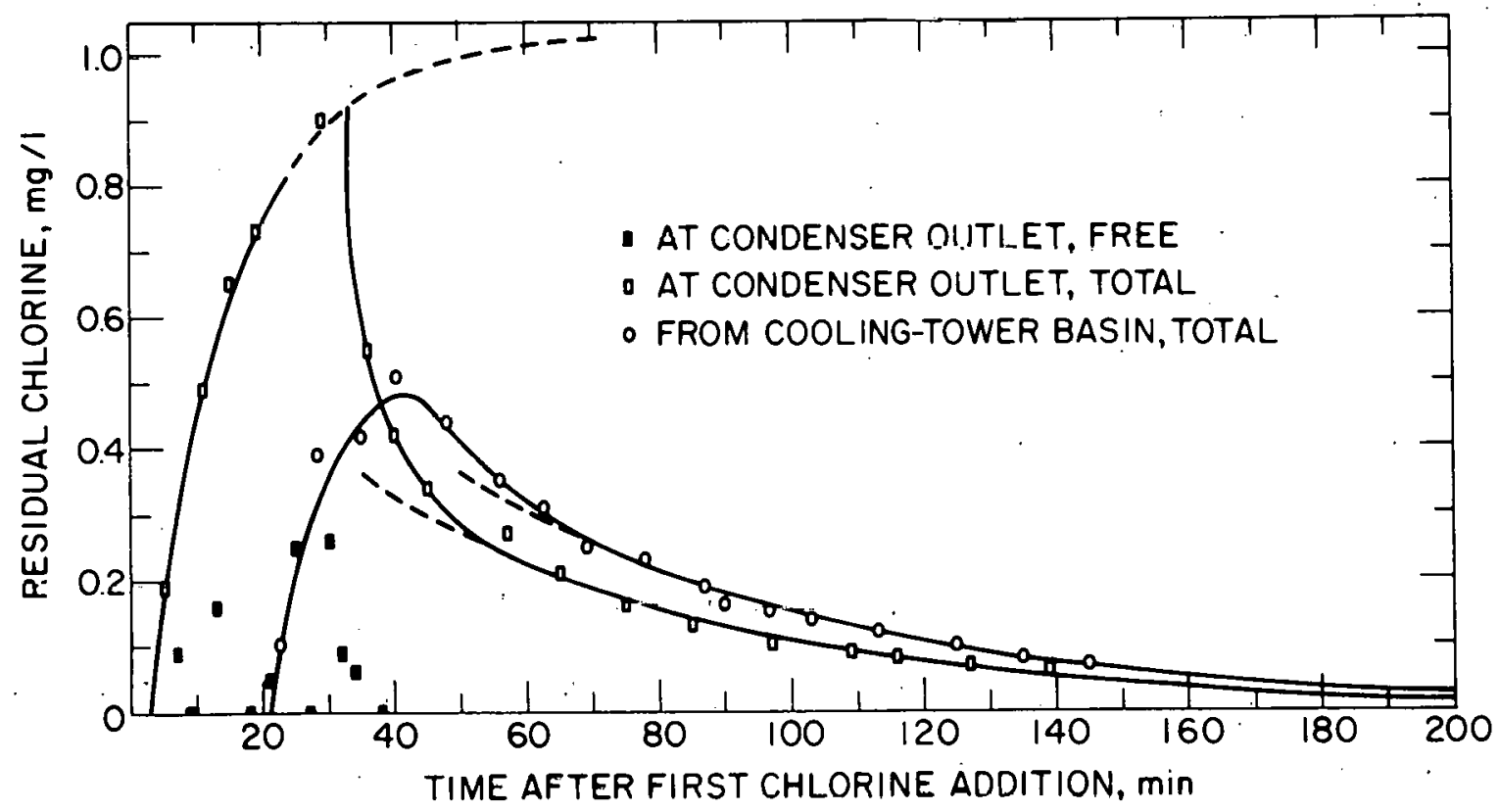

Fig. 3. Chlorination Run No. 2: April 10, 1973. (Condenser exit temperature $89^{\circ} \mathrm{F}, \mathrm{pH} 7.20-7.60$. ) 
chlorine to decrease to about 0.01 or $0.02 \mathrm{ppm}$, the sensitivity limit of the procedure used. (The accuracy of the procedure is not well known; there is no way to be certain that the small concentrations read towards the end of the decay period were truly combined chlorine or that no large errors were made.)

Although only Run 1 was made at the conditions typical at the plant, total residual chlorine had been measured under nominally identical conditions a few weeks earlier. The run was done with Unit 2 rather thau Unit 1; the water was sampled at the condenser exit, but not at the coolingtower basin. Data were similar to the curve in Fig. 2 for the total chlorine at the condenser outlet. The maximum was again $0.63 \mathrm{ppm}$, and the level dropped below the limit of sensitivity in about three hours.

Run 2 was made on the morning of April 10, with the injection rate of chlorine illereased, in the hope that the free-chlorine level would be higher and that the loss in this species during passage through the cooling tower could be estimated. In some ways the results were as anticipated, although the free-chlorine level was very erratic, showing unaccountable swings between 0 and significant valuca. This Line there were a few readings of free chlorine in the cooling-tower sluice, also erratic (not shown in Fig. 3). The irregularity might have been caused by the unusually long t1me since the last chlorination $(23 \mathrm{hr}$, rather than the usual 12). Perhaps unusually heavy deposits had formed and pieces dislodged sporadically during the cleaning, leading to depletion of the free chlorine in solution by rapid reaction with the dislodged material. At the condenser exit, the maximum recorded total residual-chlorine concentration was $0.90 \mathrm{ppm}$. 
Subtracting the maximum free-chlorine value provides an estimated maximum combined chlorine value of $0.64 \mathrm{ppm}$, about $0.1 \mathrm{ppm}$ greater than that in Run 1. The peak combined-chlorine level estimated in the same way for the cooling-tower-sluice water was $0.51 \mathrm{ppm}$, about 43 percent below the maximum at the condenser. 
4. APPLICATION OF CALCULATIONAL MODELS

Separate calculational models were used to fit the data for the increase in chlorine content during the period of addition of chlorine and for the decay after addition of chlorine was stopped. Concerning the bulldup, the slow increase in combined (or total) chlorine and the rapid decline after chlorine addition was stopped indicate consumption by reducing substances in the system that are themselves being depleted (see Figs. 2 and 3 ). On this basis, the fnllowing cupressiull was developed in which the combinedchlorine conceutration had a maximum value at the condenser that was lower than that corresponding to the rate of chlorine injection by an amount $\mathrm{K}$ :

$$
C_{\text {tot }}=\left(C_{0}-K\right)\left\{1-\exp \left[-A\left(t-t_{0}\right)\right]\right\}+C_{\text {free }} \cdot
$$

This constant is the sum of the free chlorine that remains unrearted and the amount of chlorine that was reduced by rapid-acting chlorine-demand constituents. This maximum amount of combined chlorine was diminished by reaction of the frec or combined chlorine with such things as deposits on surfaces. The braced term of Eq. 1 is developed for the case in which a constant fraction of the reactive wall material is removed for each constanttime interval. It is necessary to use $t_{0}$ to accommodate the times of passage (of injected chlorine solution and of circulating water from the point of chlorine injection to the sample point) and possible inaccuracies in watch synchronization. Finally, the total residual chlorine is the sum of the combined chlorine so estimated and the free chlorine remaining. 
This equation was fitted to the data for the buildup of chlorine at the condenser for Runs 1 and 2. Referring to Fig. 2, using three points determines the constant $A$. The remaining constants, $t_{0}, K$, and $C_{\text {free }}$, could have wide ranges of values and still provide essentially the same curve. There was, however, a requirement for certain interrelationships. For Run 1 , the condition chosen to finalize the constants was that the free chlorine had the constant value equal to the average of those observed, $0.09 \mathrm{ppm}$. The fit to the data was excellent, as can be seen in Fig. 2, where the line drawn is that of the equation from five minutes onward. The line is dashed after the first $24 \mathrm{~min}$, since the dẹivation of the equation did not consider the effect of chlorinating water that had been chlorinated on a previous pass around the system. Since the average total passage of water. through the system is $22 \mathrm{~min}$ (the volume divided by the circulating flow rate) and there is a 2 -min period from the point of chlorination to the sampling, no points for times greater than $24 \mathrm{~min}$ were used in determining the values of the constants. If the basis for the model is correct, the extended dashed line suggests that cleaning the condenser would be essentially complete only after another 20-30 min of chlorination.

For Run 2, the value of $A$ was again selected by passing the line through three of the data points before $24 \mathrm{~min}$. In the absence of a clear method for selecting values for the remaining constants, the value of $\mathrm{K}$ for Run 2 was established as the same as that for Run 1 . Choosing the same value instead for fast chlorine demand might have been better; the difference in constants would have been only slight. Again, the dashed line is an extrapolation beyond the first $24 \mathrm{~min}$ of the run. Again, the data suggest that cleaning the walls of a11 significant amounts of chlorine-consuming 
growths would require an additional period of chlorination. The values of the parameters are tabulated in Table 4. All the constants appear to be at least reasonable in magnitude, and there is fairly good correlation between the values used for the two runs. During time increments of about $14 \mathrm{~min}$ (reciprocal of $\mathrm{A}=0.07$ ), the quantity of chlorine-destroying materlal is reduced by a factor of $e$. By the choice of $k$, the level of the free chlorine (assumed to be constant during the buildup) was $0.05 .:$ In view of the irregular values obtained, there is no way to determine whether this is a good or poor apprnximation. In fact, if other values fur the, last four parameters in the table had been selected, so as to use a significantly larger value for $C_{f}$, they would still have been in the reasonable range in light of the lack of precision in the results. For example, a value of 4 for $t_{0}$ in Run 2 leads to a value of 0.13 for $C_{f}$ and 0.71 for $k$. As shown in Table 4, for the parameters chosen, the values of $\mathrm{K}-\mathrm{C}_{\mathrm{f}}$ are almost the same for Runs 1 and 2. This quantity should be a measure of the total concentration of the substances in the circulating water that quickly destroy chlorine before it can produce chloramines or react with organic deposits.

After the initial sharp decay period, the more gradual loss of combined chlorine from the system was fitted to an equation first used in August 1972 in an effort to estimate chlorine levels during and after treat - . ment of the recirculating-water system for a proposed nuclear power plant for which a license has been requested. ${ }^{3}$ Chlorine species were assumed to be lost by blowdown and by reaction within the system--as by reaction with reducing substances, evaporaclve loss in the cooling tower, or sunlightcatalyzed decomposition to form oxygen (for free chlorine). The loss within the system is given by a term, F, the fraction lost per average pass 
through the recirculating-water"system. On the basis of mass balance and the assumption of uniform composition throughout the system at any one time, the following expression was derived:

$$
V \frac{d C}{d t}=C_{M} M-C(B+F R)
$$

where $\mathrm{V}$ is the volume of the system, $\mathrm{C}$ the concentration varying with time $t, C_{M}$ the concentration in the makeup at flow rate $M, B$ the blowdown rate, and $R$ the recirculating-water flow rate. For the present application, where there is no addition of chlorine, the first term on the right, side is 0 , and integration yields the following result (the requirement for uniformity in the system also vanishes):

$$
C=C_{0} \exp \frac{-L\left(t-t_{0}\right)}{V}
$$

where $L$, the loss factor, is defined as $B+F R$.

Application of this expression to the decay period of the two lines in each of Figs. 2 and 3 provided excellent fits to the data; in fact, the. lines were drawn from the equation. They were extended backward in t1me from the first point fitting the data as dashed lines in the figures. The constants used for these lines are given in Table 4. For Run 1, the actual 
TABLE 4. Values for Parameters in Equations 1 and 3

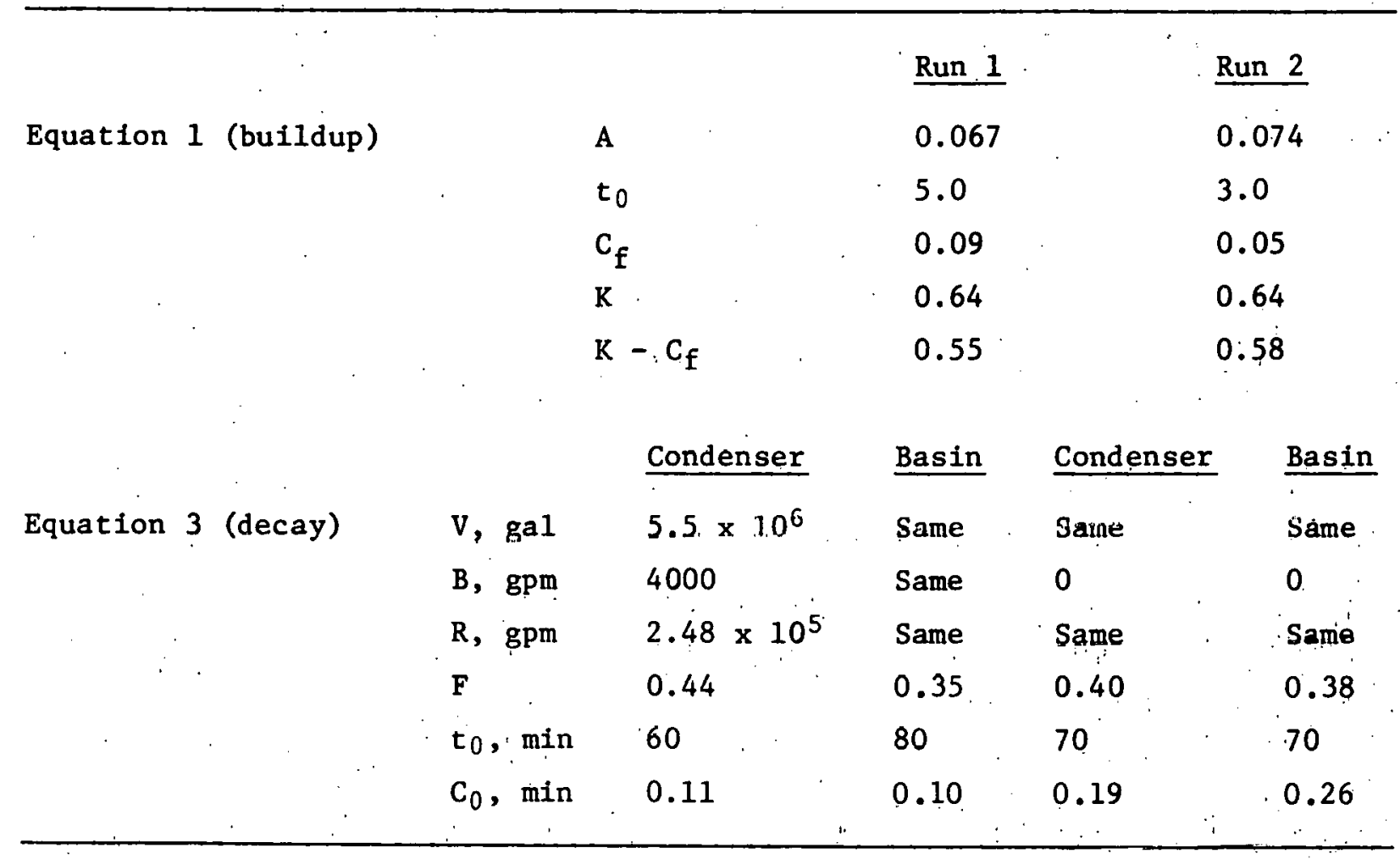


blowdown rate (about $4000 \mathrm{gpm}$ )" was used; for Run 2, since there was no blowdown, $B$ was assigned a value 0 . The only constant to which an independent value was assigned was F. Note that this factor varied from 0.35 to $0.44--$ a small range, given the differences in circumstances at the condenser and in the cooling-tower basin and differences in the rate of addition and the level of chlorine for the two runs.

It is encouraging that relatively simple calculational models provide a good approximation to the buildup and decay of chlorine during these experiments. The decay curve used (value of $F$ ) indicates that the free chlorine in the condenser discharge during Run 1 probably was converted to chloride by reaction with something in the. system before going through the cooling tower, since the fraction lost per pass (and for chloramines this very likely means loss by evaporation in the couling tower) was 0.4 rather than 0.5 (see Section 2). The applicability of the factor 0.4 to other natural-draft cooling towers should be determined. A logical basis (depending on the chemical constitution of the recirculating water) for the quick-acting chlorine demand of $0.6 \mathrm{ppm}$ for the two runs would be desirable. Unfortunately, the only chemical analyses available are for the river water. There might be enough reducing, species, such as manganous ion, ferrous ion, nitrite ion, and some organic substances, to add up to this level of quick-acting chlorine demand. If this correlation could be shown, it would provide confidence in the use of this equation in predicting the buildup of chlorine in rectrculating systems, at least during the first passage of water through the system. 
ACKNOWLEDGMENTS

The cooperation and participation of personnel of the American Electric Power Service Corporation (AEP) and the Appalachian Power Company are gratefully acknowledged. Mr. R. W. Reeves, head of the Environmental Engineering Division of the AEP, together with T. A. Miskimen of the same organization, made necessary arrangements. Mr. J. A. Moore, Manager, and Mr. M. Vaughan, Chief Chemist, at the Amos Plant authorized the necessary nonstandard operations. Messrs. Gary Crawford and Emil Hoffman, bnth AEP, did the analyses.

\section{REFERENCES}

1. Joseph E. Draley, The Treatment of Cooling Waters with Chlorine, ANL/ES-12. (Feh 1972).

2. George Clifford White, Handbook of Chlorination, Van Nostrand-Reinhold, New York, Lincinnati (1972).

3. U. S. Atomic Energy Commission, Final Environmental Statement Related to Construction of Dav1s-Besse Nuclear Power Station, Dockct No. 50=346 (Mar 1973). 